\title{
First record of the endemic anthozoan Spinimuricea klavereni (Carpine \& Grasshoff 1975) (Cnidaria, Anthozoa, Plexauridae) in the Adriatic Sea
}

\author{
Vesna MAČIĆ ${ }^{*}$, Egidio TRAINITO² and Slavica PETOVIĆ1 \\ ${ }^{1}$ Institute of Marine Biology, University of Montenegro, \\ Put I Bokeljske brigade 68, 85330 Kotor, Montenegro \\ 2 Via Corallo 11, 07020 Loiri Porto San Paolo, Italy \\ *Corresponding author, e-mail: macic.v@ucg.ac.me
}

We present the first record of the endemic Mediterranean anthozoan Spinimuricea klavereni (Carpine \& Grasshoff 1975) (Cnidaria, Anthozoa, Plexauridae) for the Adriatic Sea (Boka Kotorska bay, Montenegro). A density of 0.72 colonies $m-2$ could be measured in the area, which was compared with the scant available data in the literature. Having in mind that this species is very rare and endemic for the Mediterranean, it is important to increase our knowledge on its distribution and biology in order to better assess its ecological role, the pending threats and the need for specific conservation measures

Key words: Boka Kotorska Bay; Montenegro; Spinimuricea klavereni; Mediterranean

\section{INTRODUCTION}

The Mediterranean Sea is one of the 36-biodiversity hot spots of the World, with more than 17000 described marine taxa, with experts estimating that there are still many undescribed species (COLL et al., 2010). Unfortunately, as a centre of ancient civilizations, the Mediterranean is under constantly increasing human pressure. In recent decades, the anthropogenic impact has grown dramatically, diversifying and increasing its distribution in the basin, causing an alteration of ecosystems and a decrease in biodiversity (COLL et al., 2010, BIANCHI et al., 2012). The semi-enclosed nature of the Mediterranean Sea aggravates the multiple effects of the said impacts, whose causes have been outlined by numerous authors: professional and recreational fishing, overfishing, maritime traffic, water pollution, coastal development, introduction of nonindigenous species, and offshore oil and gas prospection and exploitation (MedPAN \& SPA/ RAC, 2019). Effects of these multiple drivers are intensified by global climate change, with the consequences of the acidification process still not foreseeable.

Having in mind the cumulative character of the ongoing process, it is not strange that many national and international initiatives are taken in order to halt biodiversity loss and plan sustainable development goals (Barcelona Convention, Bern Convention, EU Habitat directive, MSFD). One of those is the IUCN Red list of Threatened Species and Overview of the conservation status of the Mediterranean Anthozoa (OTERO et al., 2017). 
Table 1. Records of Spinimuricea klavereni based on literature and on present paper

\begin{tabular}{|c|c|c|c|c|c|c|c|}
\hline AUTHOR & YEAR & SITE & NATION & DEPTH & $\mathrm{X}$ & $\mathrm{Y}$ & NOTE \\
\hline $\mathrm{KOCH}$ & 1887 & Naples Gulf & Italy & & 14.266160 & 40.785525 & \\
\hline $\begin{array}{l}\text { CARPINE \& } \\
\text { GRASSHOFF }\end{array}$ & 1975 & Algeria & Algeria & & 3.046894 & 36.922207 & \\
\hline $\begin{array}{l}\text { CARPINE \& } \\
\text { GRASSHOFF }\end{array}$ & 1975 & Monaco & Monaco & $50 \mathrm{~m}$ & 7.436084 & 43.734130 & Harbor dike, mud \\
\hline $\begin{array}{l}\text { CARPINE \& } \\
\text { GRASSHOFF }\end{array}$ & 1975 & Samotracia & Greece & $55 \mathrm{~m}$ & 25.503408 & 40.413192 & $\begin{array}{l}\text { Calypso SME } \\
\text { station } 1613 \text {, } \\
2 \text { colonies, muddy } \\
\text { sand }\end{array}$ \\
\hline $\begin{array}{l}\text { CARPINE \& } \\
\text { GRASSHOFF }\end{array}$ & 1975 & Bosphorus & Turkey & & 29.128676 & 41.216964 & \\
\hline VIEIRA & 2008 & Algarve & Portugal & & -8.322760 & 36.953590 & Grassoff, 1992 \\
\hline AGUILAR et al. & 2008 & $\begin{array}{l}\text { Placer de la Barra y } \\
\text { Hoya, Columbretes } \\
\text { Islands }\end{array}$ & Spain & $80-90$ & 0.533333 & 39.833333 & Oceana \\
\hline AGUILAR et al. & 2008 & $\begin{array}{l}\text { Bajos del Oeste, } \\
\text { Columbretes Islands }\end{array}$ & Spain & $80-90$ & 0.700000 & 39.950000 & Oceana \\
\hline BO et al. & 2012 & $\begin{array}{l}\text { S.Eufemia Gulf S1, } \\
\text { Calabria }\end{array}$ & Italy & $70110 \mathrm{~m}$ & 16.087000 & 38.738667 & \\
\hline AGUILAR & 2014 & Formentera Island & Spain & & 1.349780 & 38.689045 & \\
\hline $\begin{array}{l}\text { TOPÇU \& } \\
\text { ÖZTÜRK }\end{array}$ & 2015 & $\begin{array}{l}\text { Marmara Sea, Balikci } \\
\text { Island (north) }\end{array}$ & Turkey & $25-38 \mathrm{~m}$ & 29.090062 & 40.861458 & $\begin{array}{l}\max \text { density } 3,1 \mathrm{~m}^{-2} \\
\text { in } 14 \text { sites }\end{array}$ \\
\hline $\begin{array}{l}\text { TOPÇU \& } \\
\text { ÖZTÜRK }\end{array}$ & 2015 & $\begin{array}{l}\text { Marmara Sea, } \\
\text { Marmara Island (south) }\end{array}$ & Turkey & $30 \mathrm{~m}$ & 27.637892 & 40.522632 & $\begin{array}{l}\max \text { density } 0,1 \mathrm{~m}^{-2} \\
\text { in } 1 \text { site }\end{array}$ \\
\hline ISPRA & 2016 & $\begin{array}{l}\text { Capo Milazzo 13, } \\
\text { Sicily }\end{array}$ & Italy & $\begin{array}{l}75- \\
101 \mathrm{~m}\end{array}$ & 15,218917 & 38,251167 & 2 colonies \\
\hline ISPRA & 2016 & $\begin{array}{l}\text { Capo Milazzo 11, } \\
\text { Sicily }\end{array}$ & Italy & $35 \mathrm{~m}$ & 15,233433 & 38,261267 & \\
\hline ECOSAFIMED & 2016 & Golfo di Patti, Sicily & Italy & $36-70 \mathrm{~m}$ & 15.074648 & 38.200576 & $\begin{array}{l}\text { average } 1 \pm 1,8 \\
\text { colonies } \\
\mathrm{m}^{-2} ; \max \\
13 \mathrm{~m}^{-2}\end{array}$ \\
\hline SANTIN \& GORI & 2018 & $\begin{array}{l}\text { Cap de Creus, } \\
\text { Catalunia }\end{array}$ & Spain & $10 \mathrm{~m}$ & 3.27766 & 42.34070 & 3 colonies \\
\hline MACIC et al. & 2021 & $\begin{array}{l}\text { Verige Turski Rt, } \\
\text { Boka Kotorska Bay }\end{array}$ & Montenegro & $28-32 \mathrm{~m}$ & 18.686263 & 42.477892 & $\begin{array}{l}36 \text { colonies; } 0,72 \\
\text { colonies } \mathrm{m}^{-2}\end{array}$ \\
\hline
\end{tabular}

The number of species of Anthozoans present in the Mediterranean Sea is quite disputed: VAFIDIS (in COLL et al, 2010) listed 167 species, including 3 introduced and 37 endemic taxa; TRAINITO \& BALDACCONI in 2016 listed 182 confirmed species, including 32 endemic and 6 introduced taxa, and 20 taxa whose taxonomic status is doubtful. In the Mediterranean Anthozoan Red List OTERO et al. in 2017 listed 212 species, including 62 whose taxonomic status is unconfirmed and 26 endemic taxa. The high level of uncertainty regarding the class of Anthozoa is confirmed by the 69 species whose status assessment is Data Deficient (OTERO et al. 2017) and this also regards endemic species. Spinimuricea klavereni (CARPINE \& GRASSHOFF 1975) is one of them.

This gorgonian species was known from the XIX century but at that time it was confused with Paramuricea placomus (described as Gorgonia placomus [Linneaus, 1758]) and it was redescribed in 1975 (CARPINE \& GRASSHOFF, 1975) as Echinomuricea klavereni, based on specimens from Monaco and Samotrakia (Aegean Sea, Greece). Its current taxonomy was established in 1992 by GRASSOFF with the 


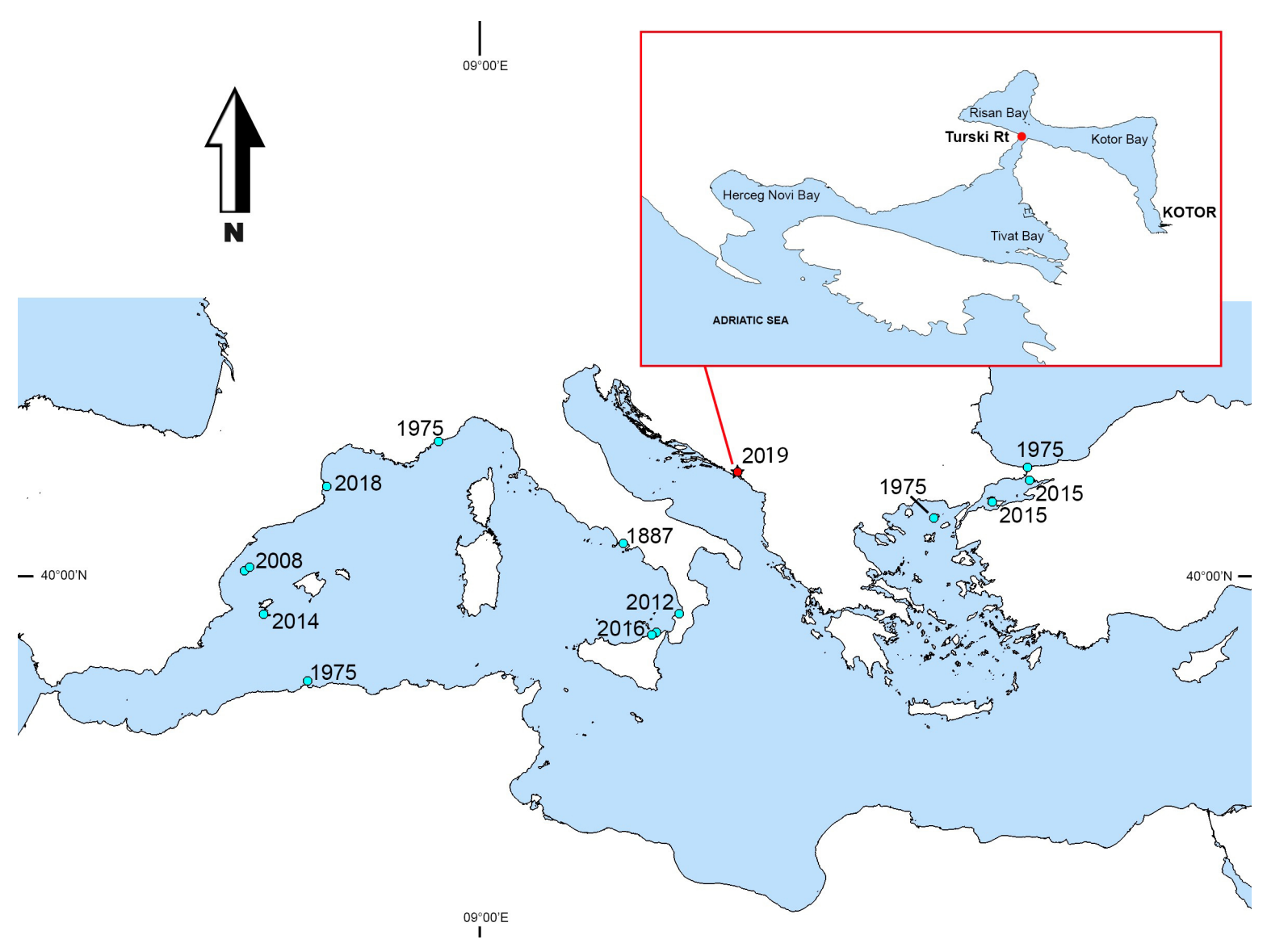

Fig. 1. Distribution of Spinimuricea klavereni records from bibliography (blue dots) and new record in the Adriatic Sea (red dot)

institution of the genus Spinimuricea, which includes also the Atlantic Spinimuricea atlantica (Johnson, 1882). The colonies of S.klavereni stand vertical with few or no branches. The basal zone is not covered by coenenchyme, while polyps are placed close to each other and more or less in two opposite rows. The colonies exceptionally may reach up to $110 \mathrm{~cm}$ height (TOPÇU \& OZTÜRK 2016a), but mostly less than $50 \mathrm{~cm}$. It is reported both on hard and muddy substrates, usually attached to stones in a depth range of $50-80 \mathrm{~m}$. On the contrary S. atlantica may be distinguished by the more ramified aspect of colonies and presence of ramified sclerites in the coenenchyme (CARPINE \& GRASSHOFF, 1975; TRAINITO \& BALDACCONI, 2016; TOPÇU \& OZTÜRK, 2016a).

When described, S. klavereni was known only for Algeria, Monaco, Bay of Naples, North Aegean Sea and Bosphorus (CARPINE \& GRASSHOFF, 1975). Up to nowadays, only several new records are added from the North Aegean Sea (VAFIDIS et al., 1994), the Sea of Marmara (TOPÇU \& OZTÜRK, 2016a), the Thyrrhenian Sea (BO et al., 2012; ISPRA, 2016; ECOSAFIMED, 2016), the Balearic Archipelago and the northern Mediterranean coasts of Spain (AGUILAR et al., 2015; SANTIN \& GORI, 2018). The reported presence of S. klavereni in the waters of Algarve (South Portugal, Atlantic Ocean) (CURDIA, 2012) needs confirmation. Recent studies in the Marmara Sea by TOPÇU and OZTÜRK (2016a, 2016b) reported the highest density of $S$. klavereni (3.1 ind. $\mathrm{m}^{-2}$ ) and highlighted depth range, morphometry, growth rates and reproduction (TOPÇU \& OZTÜRK, 2016a, 2016b). Being these the only in-depth studies on the species, it is not strange that OTERO et al., (2017) in the Overview of the conservation status of the Mediterranean Anthozoa classified $S$. klavereni as Data Deficient. Table 1 summarizes all the record of the species. Figure 1 shows the geographical distribution of the records. 
The aim of this work was to first report $S$. kalvereni for the Adriatic Sea and contribute to the knowledge of this endemic, rare and probably threatened species.

\section{MATERIAL AND METHODS}

Surveys were performed in Verige strait, Turski Rt, Boka Kotorska Bay, Montenegro (N $42.477888^{\circ} \mathrm{E} 18.686523^{\circ}$ ) by SCUBA diving in September 2019 (Fig. 1). After preliminary surveys, a rectilinear video and photo-transect of $100 \mathrm{~m} \times 0.5 \mathrm{~m}$ were performed in correspondence with the presence of the colonies of S. klavereni. The video was performed with a Go Pro camera and photographs with a SONY a6000, APSC, 24-megapixel, 16-55 mm lens in Sea \& Sea housing with wetlens Nauticam WW1, macro shots were taken with $30 \mathrm{~mm}$ lens. All colonies along the transect were counted and three samples were collected. One sample was treated with $30 \%$ hydrogen peroxide to extract the sclerites for taxonomic determination. Sclerites were examined and photographed with Zeiss Axio Imager.A1. Samples are stored at the Institute of Marine Biology, Kotor, University of Montenegro.

\section{RESULTS}

Spinimuricea klavereni colonies were observed on an almost horizontal muddy bottom from 28 to $32 \mathrm{~m}$ depth. Colonies were white, almost all unbranched and approximately 5 to 28 $\mathrm{cm}$ high (Fig 2). The sclerites extracted from the collected sample indicate thornscales from the calix (Fig 3A) and spindles or needles from the coenenchime (Fig 3B). The comparison with the images presents in the literature corroborates the identification of $S$. klavereni both based on of the external morphology and of the structure of sclerites (CARPINE \& GRASSHOFF, 1975; SANTIN \& GORI, 2018). Therefore, this is the first report of the species for the Adriatic Sea.

All the colonies in the area of the transect were counted giving a density of 0.72 colonies $\mathrm{m}^{-2}$, which is consistent with the range of densities known from the poor data available in the

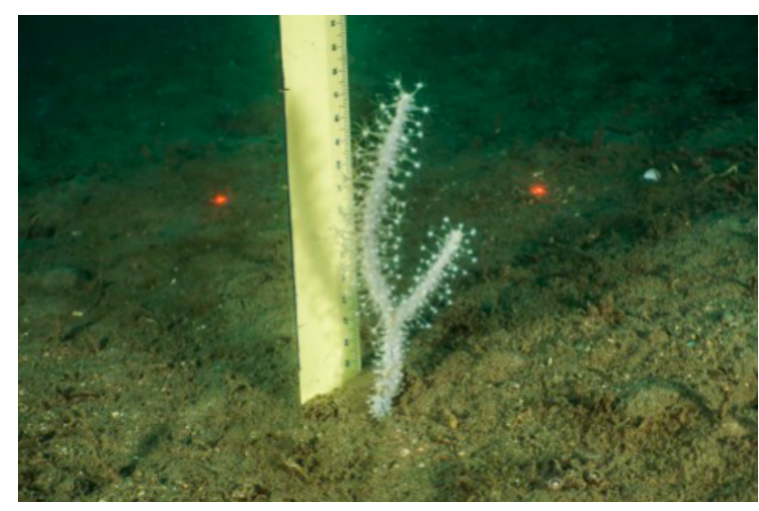

Fig. 2. Spinimuricea klavereni, Verige strait, Adriatic Sea

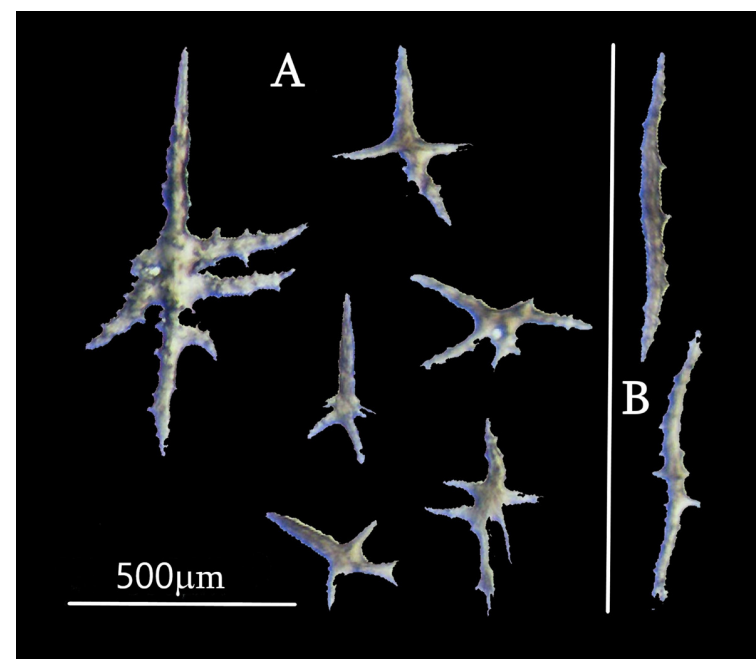

Fig. 3 The sclerites extracted from the collected sample of Spinimuricea klavereni: A) thornscales from the calix, $B)$ spindles or needles from the coenenchyma

literature. As depicted in Table 1, the density was measured in the Marmara Sea in a range of 0.1-3.1 colonies $\mathrm{m}^{-2}$ (TOPÇU \& OZTÜRK, 2015) and 1-1.8 colonies in the Patti Gulf (ECOSAFIMED, 2016). All other records refer to few or single individuals.

None of the colonies in the surveyed site was affected by epibiosis or necrosis.

\section{DISCUSSION}

This rare gorgonian species typically inhabits depths below recreational diving (Table 1) and this could be one of the reasons for the lack of knowledge on its distribution and biology in general (TOPÇU \& OZTÜRK, 2013, 2016a). Exceptionally shallow and dense populations of Spinimuricea klavereni in Marmara Sea gave the 
opportunity for the first studies on the growth rate and reproduction of this species (TOPÇU \& OZTÜRK, 2016a, 2016b). Furthermore, it seems that this dense population could be a result of the specific oceanographic conditions of the Marmara Sea. This semi-enclosed sea connects the Black Sea and the Aegean Sea and it is characterized by vertical stratification and brackish water at the surface (TOPÇU \& OZTÜRK, 2016b). Interestingly, the Verige strait where $S$. kalvereni was reported for the first time in the Adriatic Sea could be compared to the Marmara Sea. This is the narrowest part of the Boka Kotorska Bay (Fig. 1) and connects the inner part of the bay, characterized by a strong inflow of freshwater springs (mostly during winter) and several "vrulja" (underwater springs of freshwater), with western part connected to the open sea (BELLAFIORE et al., 2011).

Currents in the Verige strait are usually strong and at the upper layers brackish water flows toward the open sea, while in the deeper layers currents are toward the inner part of the bay. Furthermore, Boka Kotorska Bay is under strong anthropogenic impact first of all because of eutrophication and habitat destruction (DRAKULOVIĆ et al., 2016; MAČIĆ \& ZORDAN, 2018). On the coast along the site of the here described finding of $S$. klavereni just a few years ago a new infrastructure was built and, unfortunately, habitat destruction on the bottom of the sea is very evident: the dumping of building materials, and of a huge amount of marine litter of any dimension (plastic waste, cars, a rubbish container, a bus) was favored by the proximity of the road to the sea coast.

Despite these anthropogenic conditions, the population of S.klavereni showed no signs of degradation: this is consistent with the opportunistic behavior of the species as described by TOPÇU \& OZTÜRK (2016a) reporting the low necrosis and high growth rates in the Marmara populations.

\section{CONCLUSIONS}

Further analyses are needed in Boka Kotorska Bay to point out the characteristics of this population and its evolution in time and space; it will be also of primary importance to investigate the possible presence of other similar populations in the bay. Having in mind that $S$. klavereni is very rare and endemic for the Mediterranean, it is important to increase our knowledge on its distribution and biology in order to better assess its ecological role, the pending threats and the need for specific conservation measures.

\section{AKNOWLEDGEMENTS}

The data here reported were collected in the frame of the project "Agreement between UNEP and PAP/RAC, UNEP/ PCA/ECOSYSTEMS/2017/MCEB.-MAP/025".

Egidio Trainito operated on the basis of Contract no. 16/OP/2019: CAPACITY BUILDING FOR ASSESSMENT OF CORALLIGENOUS COMMUNITIES IN MONTENEGRO, RELEVANT FOR GES and GEF Adriatic project.

Conflicts of Interest: The authors declare no conflict of interest. The funders had no role in the design of the study; in the collection, analyses, or interpretation of data; in the writing of the manuscript, or in the decision to publish the results.

\section{REFERENCES}

AGUILAR, R., S. GARCIA, B. ÖZTÜRK, M. BO, A. TERRÓN-SIGLER, C.L. LINARES \& B. OZALP. 2015. Spinimuricea klavereni (errata version published in 2017). The IUCN Red List of Threatened Species 2015: e.T50012660A112093393 https://dx.doi.org/10.2305/IUCN.UK.2015-2.
RLTS.T50012660A11209 3393.en. Downloaded on 28 April 2020.

AGUILAR, R., S. GARCIA, B. ÖZTÜRK, M. BO, A. TERRÓN-SIGLER, C.L. LINARES \& B. OZALP. 2015 Spinimuricea klavereni (errata version published in 2017). The 
IUCN Red List of Threatened Species 2015: e.T50012660A112093393. https:// dx.doi.org/10.2305/IUCN.UK.2015-2.RLTS. T50012660A112 093393.en. Downloaded on 05 May 2020.

BELlAFIORE, D., A. GUARNIERI, F. GRILLI, P. PENNA, G. BORTOLUZZI, F. GIGLIO \& N. PINARDI. 2011. Study of the hydrodynamical processes in the Boka Kotorska Bay with a finite element model. Dynamics of Atmospheres and Oceans 52 (2011): 298- 321.

BO, M., S. CANESE, C. SPAGGIARI, A. PUSCEDDU, M. BERTOLINO, M. ANGIOLILLO, M. GIUSTI, M.F. LORETO, E. SALVATI, S. GRECO \& G. BAVESTRELLO. 2012. Deep coral oases in the South Tyrrhenian Sea. PLoS-One 7: e49870. BIANCHI C.N. C. MORRI, M. CHIANTORE, M. MONTEFALCONE, V. PARRAVICINI \& A. ROVERE. 2012. Mediterranean Sea biodiversity between the legacy from the past and a future of change. In: Life in the Mediterranean Sea: A Look at Habitat Changes Editor: Noga Stambler. pp: 1-55 ISBN: 978-1-61209-644-5.

CARPINE, C. \& M. GRASSHOFF. 1975. Les Gorgonaires de la Méditerranée. Bull. Inst. Oceanogr. Monaco 135: 31-36.

CÚRDIA J.L.S. 2012. Gorgonians of the south of Portugal: biology, ecology and conservation. Universidade de Aveiro Departamento de biologia, $\mathrm{PhD}$ thesis, 296p.

GRASSHOFF, M. 1992. Die Flachwasser-Gorgonarien von Europa und Westafrika (Cnidaria, Anthozoa) 1992. 135 seiten, 155 abbildungen, 7 tafeln, Courier Forschungsinstitut Seckenberg, band 149.

COLL, M, C. PIRODDI, J. STEENBEEK, K. KASCHNER, L. BEN RAIS, et al. 2010. The biodiversity of the Mediterranean Sea: estimates, patterns, and threats. Plos one 5(8): e11842. Doi:10.1371/journal.pone.0011842

DRAKULOVIĆ, D., B. PESTORIĆ, R. KRAUS, S. LJUBIMIR \& S. KRIVOKAPIĆ. 2016. Phytoplankton Community and Trophic State in Boka Kotorska Bay. A. Joksimović et al. (Editors), The Boka Kotorska Bay Environment, Hdb Env Chem, DOI 10.1007/698_2016_30,

ECOSAFIMED 2016. Towards Ecosystem Conservation and Sustainable Artisanal Fisheries in the Mediterranean basin - Executive Report. ISPRA, 2016. Sudio propedeutico all'istituzione dell'Area Marina Protetta "Capo Milazzo" e proposta di zonazione. Convenzione DPNMISPRA per la collaborazione all'istituzione delle aree marine protette "Capo Milazzo", Grotte di Ripalta-Torre Calderina", "Costa del Monte Conero" e "Capo Testa-Punta Falcone" PR ISPRA 33018.

MAČIĆ, V. \& C. ZORDAN. 2018. Mapping of the Cymodocea nodosa (Ucria) Asch. meadows in the Kotor bay and data comparison over the last four decades. Studia Marina 31 (1): 5-15.

MedPAN \& SPA/RAC, 2019. The 2016 status of Marine Protected Areas in the Mediterranean. By Meola B. and Webster C. Ed. SPA/RAC $\&$ MedPAN. Tunis 222 pages.

OTERO, M.M., C. NUMA, M. BO, C. OREJAS, J. GARRABOU, C. CERRANO, P. KRUŽIĆ, C. ANTONIADOU, R. AGUILAR, S. KIPSON, C. LINARES, A. TERRÓN-SIGLER, J. BROSSARD, D. KERSTING, P. CASADO-AMEZÚA, S. GARCÍA, S. GOFFREDO, O. OCAÑA, E. CAROSELLI, M. MALDONADO, G. BAVESTRELLO, R. CATTANEO-VIETTI \& B. ÖZALP. 2017. Overview of the conservation status of Mediterranean anthozoans. IUCN, Malaga, Spain. $\mathrm{x}+73$ pp.

SANTÍN, A. \& A. GORI. 2018. 1.2 New records of the endemic gorgonian Spinimuricea klavereni (Carpine \& Grasshoff, 1975) (Alcyonacea: Plexauridae) in the Western Mediterranean Sea in New Mediterranean Biodiversity Records. Medit. Mar. Sci., 19/3, 2018, 673689.

TOPÇU, N.E. \& B. ÖZTÜRK, 2013. Octocoral diversity of Balıkçı (Neandros) Island, Marmara Sea. J. Black Sea/ Mediterr. Environ. 19 (1): 468-480.

TOPÇU N.E. \& B. ÖZTÜRK. 2016a. First insights into the demography of the rare gorgonian Spinimuricea klavereni in the Mediterranean Sea. Mar. Ecol. doi: 10.1111/maec.12352.

TOPÇU N.E. \& B. ÖZTÜRK. 2016b. Reproduction in the Mediterranean endemic gorgonian Spinimuricea klavereni (Anthozoa, Octocorallia, Plexauridae). Invertebrate Biology 135(1): 13-19. 
TRAINITO E. \& R. BALDACCONI. 2016. Coralli del Mediterraneo. Il Castelo, 176p.

VAFIDIS, D., A. KOUKOURAS \& E. VOULTISIADOU-

KOUKOURA. 1994. Octocoral fauna of the
Aegean Sea with a check list of the Mediterranean species: new information, faunal comparisons. Ann. Irw. oceanogr., Paris, I 994, 70 (2): 2 I 7-229.

Received: 22 May 2020

Accepted: 26 May 2021 


\title{
Prvi nalaz endemskog žarnjaka Spinimuricea klavereni (Carpine \& Grasshoff 1975) (Cnidaria, Anthozoa, Plexauridae) u Jadranskom moru
}

\author{
Vesna MAČIĆ* Egidio TRAINITO i Slavica PETOVIĆ
}

\section{SAŽETAK}

Prikazan je prvi nalaz endemičnog sredozemnog žarnjaka Spinimuricea klavereni (Carpine \& Grasshoff 1975) (Cnidaria, Anthozoa, Plekauridae) za Jadransko more (Bokokotorski zaliv, Crna Gora).

Dobijeni rezultati i izmjerena gustina od 0,72 kolonije $\mathrm{m}^{-2}$ su uspoređeni s oskudnim podacima dostupnim u literaturi. Imajući u vidu da je ova vrsta vrlo rijetka i endemska za Sredozemno more, važno je poboljšati znanje o njenoj distribuciji i biologiji kako bismo bolje procijenili njenu ekološku ulogu, prijetnje i potrebu za određenim mjerama zaštite.

Ključne reči: Bokokotorski zaliv; Crna Gora; Spinimuricea klavereni; Sredozemno more 